\title{
İKİ KULE BİR EFSANE: BURANA VE İSTANBUL KIZ KULELERİ
}

\section{THE TWO TOWERS - ONE LEGEND: THE BURANA TOWER AND THE MAIDEN'S TOWER OF ISTANBUL}

Hüseyin SATICIOĞLU*

\begin{abstract}
$\ddot{O} z$
Insanoğlu yaratılıştan beri içinde yaşadı̆̆ çevreyi tanıma, yorumlama ve anlamlandırma arzusunda olmuştur. Efsaneler; insanoğlunun tabiat olaylarını, mimari yapıları, toplumsal olayları yorumlama ve anlamlandırma amacı doğrultusunda ortaya çıkmış sözlü edebiyat hazinelerindendir. Tarihî süreç içerisinde çeşitli sebeplerden dolayı dünyanın farklı yerlerine göç eden Türkler, yeni yurtlarına inançlarını ve kültürlerini de taşıyarak bunları yer adlandırmalarında kullanmışlardır. Yeni yurtlarındaki mimari yapıları ve coğrafi unsurları adlandırırken yeni efsaneler de oluşturarak onlara yeni bir ruh ve kimlik kazandırmışlardır. Üretilen toponimik efsaneler coğrafyanın vatanlaştırılmasına büyük katkı sağlamıştır. Bu bağlamda, coğrafi olarak birbirinden uzak, son yüzyıllarda farklı tarihî süreçlerden geçmiş, farklı siyasi sinırlara ve yaşam şartlarına sahip olan Kırgız Türklerinin Burana Kulesi ve Türkiye Türklerinin İstanbul Kız Kulesi etrafinda oluşturdukları efsanelerdeki benzerlikler oldukça dikkat çekicidir.

Söz konusu çalışmada; Kırgızistan'daki "Burana Kulesi" ve Türkiye'deki "İstanbul Kız Kulesi"nin öncelikle tarihî, işlevsel ve mimari özellikleri ele alınmıştır. Bu mimari eserlere atfedilen efsaneler metin merkezli kuramlardan değişken ve değişmezleri esas alan yapısal çözümleme yöntemi ve bağlam merkezli kuramlardan işlevsel halkbilim yaklaşımı çerçevesinde incelenerek olay örgüsü, içerik ve şahıs kadrosu açısından karşılaştırılmıştır. Bu iki efsanedeki benzerlik ve farklılıkların hangi sebeplerden kaynaklanmış olabileceği; göç, kültür ve halk anlatısı olguları arasında ilişki olup olmadığı ve bu efsanelerin aynı ana kaynaktan beslenip beslenmedikleri tartışılarak açıklanmaya çalışılmıştır.
\end{abstract}

Anahtar Kelimeler

Folklor, efsane, kule, Burana Kulesi, İstanbul Kız Kulesi

Abstract

Since humans were created, they had sought to recognize, interpret and conceptualize the environment in which they had been living. Legends are treasures of oral literature that have appeared for the purpose of interpreting and understanding natural phenomena, architectural structures, and human social events. During the historical process, the Turkic peoples, because of various reasons, migrated to different parts of the world. They carried their beliefs and cultures to their new homeland and used them in place naming. While naming the architectural structures and geographical elements in their new homelands, they also created new legends, giving them a new spirit and identity. Thus, toponymic legends made a great contribution to the nationalization of the

\footnotetext{
* Okutman, Kırgızistan-Türkiye Manas Üniversitesi Yabancı Diller Yüksekokulu / Doktora Öğrencisi, Bişkek Devlet
} Üniversitesi Folklor Bilim Dalı, e-posta: huseyin.saticioglu@manas.edu.kg, ORCID: 0000-0002-4399-6800 
geography. In this context, despite geographical remoteness and passing through the different historical processes in the last century, different living conditions and political borders, the similarities in the legends about the Burana Tower in Kyrgyzstan formed by Kyrgyz Turks and the Maiden's Tower in Istanbul of the Turks of Turkey are quite remarkable.

In this study, the historical, functional and architectural features of the "Burana Tower" in the Chui region of Kyrgyzstan and the "Maiden's Tower"in Istanbul, Turkey were discussed. The legends attributed to these architectural works were compared in terms of the plot, content and typology. They were analysed from text-centered theories based on variables and invariants in the comparison between texts by the method of structural analysis and context-centered theories within the framework of the functional folklore approach. In this study it has been tried to explain the probable reasons of the similarities and differences in these two legends; whether there is a relationship between migration, culture and public narrative facts; it is discussed whether these legends are fed from the same main source.

\section{Keywords}

Folklore, legend, tower, the Burana Tower, the Maiden's Tower of Istanbul 


\section{Gíriş}

Türk Dünyası, dünyanın en geniş etno-kültürel coğrafyasıdır. Türk boyları tarih boyunca çeşitli sebeplerden dolayı dünyanın farklı coğrafyalarına göç etmişlerdir. Bu göçler esnasında ve yeni yurtlara yerleşim gerçekleştiğinde farklı milletlerle ve kültürlerle sosyo-kültürel etkileşime geçmişlerdir. Bu etkileşimler neticesinde kültürleşme meydana gelmiş ve folklor ürünleri de zenginleşmiştir. Türk halklarının sözlü anlatı ürünleri kabul ettikleri dinlerden, yeni komşularının inanç ve kültürlerinden etkilenmiştir. Anonim halk edebiyatı ürünlerinden olan efsane; anlatıcısı ve dinleyicisi tarafından gerçekliğine inanılan olağanüstü olayları ve kişileri konu edinen, kuşaktan kuşağa sözlü aktarım yoluyla geçen, günlük konuşma dilinde, yalın ve didaktik bir anlatıma sahip türdür. Efsaneler, belirli bir zamana ve mekâna bağlı olmalarına rağmen farklı coğrafyalara ve kitlelere de yayılabilmektedirler. Gerçek veya gerçekleşmesi mümkün olan olaylara dayanan ve şahıs kadrosu doğaüstü nitelikler taşımayan efsanelerle de karşılaşmak mümkündür. Efsane türü, diğer folklor ürünlerine nazaran daha geniş bir konu yelpazesine sahip olması, geniş bir yaş grubuna ve sosyal sınıfa hitap etmesinden dolayı inanç ve kültür mirasını nesilden nesile taşıyan işlevsel bir araçtır. Günümüzde Türk Dünyası coğrafyasındaki efsanelerde; farklı kültür, mitoloji ve inançlardan izler görmek mümkündür. Zaman içerisinde yurt edindikleri yerlerde yaşayan komşularının efsanelerinden ve inançlarından alıntı yapmayı tercih etmişler veya komşularının efsanelerini kendilerine mâl etmişlerdir. Fakat yüzyıllarca birbirlerine uzak coğrafyalarda yaşamalarına, aralarındaki sosyal ilişkilerin kopmasına rağmen sahip olunan güçlü gelenek sayesinde birçok folklor ürününde ortak tip, motif ve muhtevayı koruyabilmişlerdir.

Kente ait imgelerin tespit edilmesi, kentin kültürel kimliğinin anlaşılmasında ve oluşturulmasında önemli bir işleve sahiptir. Bu imgelerin bir kısmı mekânlar; ticari alanlar ve mimari eserler, kent ve çevresinde yetişen ürünler gibi somut unsurlar olmakla birlikte onların çevresinde oluşan pek çok gelenek de kent insanının kültürel yapısına katkıda bulunur. Örneğin; çeşitli bölge veya yapılar şehrin buluşma mekânları haline gelir. (...) Yine yapılarla ilgili anlatmalar, çeşitli inanç ve uygulamalar da kent kültürü için önemlidir (Fedakar, 2013, s. 229-230).

Toplumlar için yaşadıkları yerler kutsal ve değerlidir. Bir mekânın ve tabiat oluşumunun en ayırt edici özelliği adıdır. Toplumlar, yaşadıkları mekânları ve bu mekânlardaki tabiat oluşumlarını tarihî ve kültürel birikimlerinden faydalanarak özenle adlandırmışlardır. Mekânları adlandırırken kimi zaman mekân çevresinde efsaneler oluşturmuş, kimi zaman da olağanüstü olaylara ve efsanelere dayanılarak mekânlara ad vermişlerdir. Bir mekân çevresinde meydana gelen ve anlatılmaya devam eden efsaneler, tabiat ve insanoğlu arasındaki ilişkiyi en iyi yansıtan anlatılardır. Efsane hem toplum hem de coğrafya açısından tarihî ve kültürel bir bellektir. Toplumların kimliğini oluşturan kültürel mirasından derin izler taşımaktadır. Mekânlara, tabii oluşumlara ve mimari yapılara değer ve kutsallık kazandıran o çevrede hayat süren toplumun yarattığı inançları ve efsaneleridir.

Coğrafyanın orada yaşayan kitleler tarafından sahiplenilmesinde ve herhangi bir toprak parçasının ruh ve kimlik kazandırılarak yurt yapılmasında efsaneler önemli bir rol üstlenmektedir. Bu bağlamda, toponimik efsanelerin bir kısmının oluşumunda yabancı kökenli sözcüklerin Türkçe ses kurallarına göre yorumlanmış ve üretilen bir öyküyle yer adı anlamlandırılmıştır. Bu konuda birkaç örnek vermek yerinde olacaktır:

1. İstanbul: Roma İmparatoru Büyük Konstantinus'un ölümünden sonra, onuruna 
"Konstantinopolis" denmiş ve günlük konuşmada kullanılan eis ten polin (Yunancada "kentte" ya da "kente") biçimindeki cümlecik Osmanlı Dönemi'nde Stimbol, Estanbol, İstambol gibi değişimler geçirdikten sonra İstanbul'a dönüşmüştür (Güner \& Ertürk, 2004, s. 47-48). Bir rivayete göre, şehrin adı Müslüman ahalisi bol anlamında İslambol'dan gelmektedir. Bu rivayetin kaynağı Sultan 3. Mustafa'nın hatt-ı hümâyunlarında özellikle 'İslam şehri' anlamına gelen İslambol'u kullanmış olması olabilir.

2. Konya: Şehrinin eski adı olan İkonion, "tasvir" ya da "kutsal tasvir" anlamina gelen "ikon" sözcügüule ilişkilendirilmektedir. Kentin adına ilişkin söylencelerden birinde, ismin kökeni şu şekilde açıklanmıştır: "Horasan'dan iki derviş uçarak kendilerine yurt bulmak amacıyla Anadolu'ya gelmiş. Tam Konya üzerine geldiklerinde yeşil bir düzlük görerek dervişin biri arkadaşına sormuş: Konalım mı? Arkadaşı cevap vermiş: Kon ya! O günden sonra kondukları şehrin adı Konya olmuş."

3. Amanos Dağlarının adı ile ilgili bir efsane anlatılmaktadır: "Osman, Gülbahar adlı bir kıza âşık olur. Önce delikanlının başka bir aşiretten olduğu için kızını vermek istemeyen babası dağdan geçit açması şartıyla Gülbahar'ı vermeye razı olur. Bu gerçekleşmesi imkânsız şartı yerine getirmek isterken Osman taşlarmn altında kalır ve ölür. Haberi alan genç kız 'Aman Osman!', 'Aman Osman!' diye feryat ederek kendini yamaçtan aşă̆̆ boşluğa bırakarak hayatına son verir. O günden sonra bu dağlar Amanos diye anılır." Toros Dağ zincirinin en güneydeki kısmını oluşturan Amanos Dağları, Asur yazıtlarında Hamanu; Yunan kaynaklarında Amanos, Amanon, Melantion; Bizans ve Latin kaynaklarında ise Amanus şeklinde karşımıza çıkmaktadır. Üç efsanede de yabancı bir dilde olan yer adı Türkçe sözcüklere benzetilerek üretilen bir öyküyle anlamlandırılmıştır.

Milli kimliğin oluşumunda önemli bir yere sahip olan destanları da bu bağlamda değerlendirmek gerekir. Kırgızistan'da Manas Destanı'nı kaynaklı birçok toponim bulunmaktadır. Oş şehrinin adı Manas'a kahramanlığı öğreten hocası Oşup Bahadır'a, Kegeti köyünün adı Manas'ın çerilerinden Kegenti'ye, Koşoy Korgon Harabelerinin adı Manas'ın komutanlarından Koşoy Bahadır'a dayandırılmaktadır. Destan türünün coğrafi adlandırmalardaki rolünü örneklendiren bu adlandırmalar; hem coğrafyaya destanla bir ruh ve kimlik kazandırıldığının hem de kahramanların isimlerinin bölge halkı tarafından sahiplenilerek coğrafyada yaşatılmak istendiğinin göstergesidir.

Kuzeydoğu Anadolu, Azerbaycan ve Türkistan kültürel coğrafyasında yayılış göstermiş olan Dede Korkut Hikâyeleri Türk dili, edebiyatı, tarihi ve kültürü alanında eşsiz bir eserdir. Dede Korkut Kitabı'nda yer alan şahıs ve boy adlarının mekân adlarına dönüştürülmesiyle oluşan toponimler Anadolu coğrafyasına nakşedilen Türk damgaları olmuştur. Arız, Avşar, Basat, Bayındır, Elalmış Evren, Dündar, Kaçar, Karaman, Kınık, Salur, Yazır vb. toponimler Anadolu'nun dört bucağında kendini göstermektedir (Hacaloğlu \& Memişoğlu, 2005, s. 778). Folklor ürünleri; hem toplumun hem de coğrafyanın kimliğini ve kültürünü oluşturan, kuşaklar kuşağa taşıyan ve koruyan bir araçtır. İnsan, toplum ve mekân arasında bir bağ görevi görmektedir. Coğrafya ve toplumun kültürel belleğidir.

\section{Burana ve İstanbul Kız Kulelerinin Mimarisi, Tarihî ve Güncel Durumu}

Kırgızistan'ın Çüy bölgesindeki "Burana Kulesi” ve Türkiye'nin İstanbul şehrindeki "Kız Kulesi" öncelikle tarihî, işlevsel ve mimari özellikleri açısından ele alınmıştır. Çünkü efsanelerin oluşumunda sadece anlatıcıların değil; coğrafi şekillerin veya mimari yapıların özelliklerinin, sosyal çevrenin, tarihî ve güncel kullanımın da büyük rolü vardır. Toponimik efsaneler tabii olarak mekâna bağlı olarak ortaya çıkmıştır. Coğrafi şeklin veya mimari eserin çevresinde yaşan halk benzetme, akıl yürütme, anlamlandırma gibi süreçlere inanç ve kültürlerini de ekleyerek efsaneleri yaratmıştır. 


\subsection{Burana Kulesi}

Burana, Kırgızistan'ın başkenti Bişkek'e $81 \mathrm{~km}$ uzaklıkta, Tokmok ilçe merkezinin $12 \mathrm{~km}$ güneybatısında yer alan antik bir kentin ismi olarak kullanılmaktadır. Burana olarak adlandırılan bu harabeler aslında Türgiş (699-766), Karluk (766- 840) ve Karahanlı (840-1212) devletlerinin başkentliğini yapmış olan Balasagun'dur.

Çu (Çüy) Vadisinde yer alan şehrin bugünkü kalıntıları 10-12. yüzyıllarda Türkistan'da hüküm süren Çiğil boyuna mensup Karahanlılar Devleti tarafından 10. yüzyılın ikinci yarısında inşa edilmiştir (Törökanov, 1989, s. 3). Günümüzde, başta

11. yüzyılda kaleme alınan Kaşgarlı Mahmud'un ve Yusuf Has Hacip'in

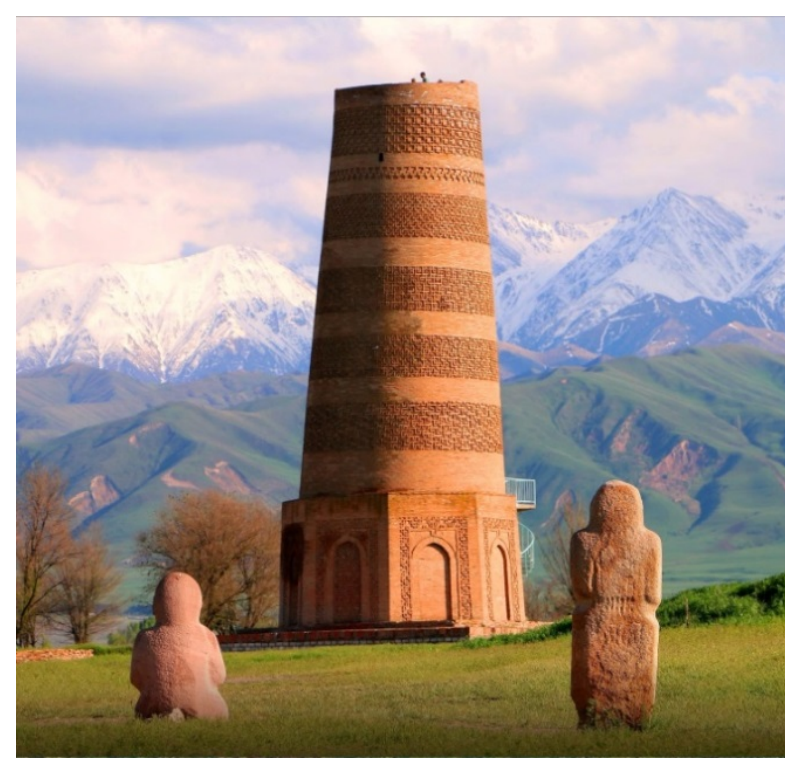

Fotoğraf 1. Burana Kulesi ve Balballar, 2017. eserleri olmak üzere diğer yazılı kaynakların incelenmesi neticesinde elde edilen bilgiler, Karahanlı hanedanının Çiğil boyu etrafında meydana geldiği tezini de güçlendirmektedir (Kanimetov \& Esenaliyeva, 2014, s. 107). Balasagun, hem İpekyolu üzerinde yer alan önemli bir ticaret merkezi hem de Karahanlı ordusunun stratejik harekât merkezi olmuştur. Kaşgarlı Mahmud'un Dîvânü Lugati't-Türk adlı eserinde şehir "Balasagun", "Koz Uluş" ve "Koz Ordu" adlarıyla anılmaktadır (Asanov, 2004, s. 338). Balasagun şehri; Karahanlı Devleti'nden sonra yaklaşık 1130'larda Kara Hitayların, daha sonra Moğolların eline geçmiş ve onlar da Balasagun'u başkent yapmışlardır. Moğollar bu şehre Go Balık (güzel şehir) adını vermişlerdir. Moğolların bu şehri aldıktan sonra tahrip etmedikleri gibi tam tersine korudukları bilinmektedir (Buyar, 2017, s. 549). Doğu Türklerinin merkezi kutsal Ötüken Dağı'na eşdeğer olarak, Batı Türkleri de Argu'da bir dağı kutlu bir merkez saymışlardı. Omeljan Pritsak'a göre, bu mukaddes dağın bulunduğu Argu bölgesi ve oradaki Taraz ve Suyab-Balasagun gibi Türk başkentlerine hâkim olan devlet, Batı Türk Dünyasının başına geçmiş sayılıyordu (Esin, 1978, s. 156). 13 ve 14. yüzyıla kadar varlığını sürdüren şehir, bu yüzyıllardan itibaren eski önemini kaybetmesinden dolayı şehir halkı yavaş yavaş göç etmeye başlamıştır (Ürekli, 2018, s. 204). 16. yüzyılda Balasagun'dan geçen Keşmir'in Türk Hükümdarı Mirza Muhammet Haydar Duğlat; sadece bir cami, bir medrese ve büyük bir şehir harabesiyle karşılaşmıştır (Asanov, s. 339).

Kırgız Türkçesinde minare kelimesinin karşıllğı "munara"dır. Barthold, günümüzde bu bölge için kullanılan "Burana" isminin tarihî başkentten kalma yegâne yapı olan minareden geldiğini, Arapçadaki manaranın bozuk telaffuzu olduğunu savunmaktadır (2004, s. 74). Burana Kulesi'nin $7 \mathrm{~km}$ kuzeybatısında 5 ve 6. yüzyıllarda İpekyolu'nun en önemli şehri ve Batı Göktürk Kağanlığının başkenti olan Ordukent'in (Suyap) harabeleri bulunmaktadır. Bu şehir Balasagun ile iç içe geçmiş ve birbirlerinin devamı olmaları sebebiyle birçok tarihçi tarafından birlikte değerlendirilmektedir. Ayrıca günümüzde bölgede Burana adında bir köy de mevcuttur.

Arkeolog Mihail Masson yaptığı kazılar sonucunda, Burana Kulesi'nin 11. yüzyılın birinci yarısında yapıldığını tespit etmiş ve bu tespit çoğu araştırmacı tarafından da kabul görmüştür. 
Kulenin ilk yapıldığındaki yüksekliği 45 metredir. En tepesine özel bekçi yeri (manzar) yapılarak, tepesi kubbe şeklinde kapatılmış ve etrafına pencere açılmıştır. Baş tarafının 15 ya da 16. yüzyıllardaki büyük depremlerin birinde yıkıldığı ve kulenin 6 derece batıya eğimli hale geldiği tahmin edilmektedir. Günümüze 24,6 metrelik kısmı ulaşmıştır. Kule; sekizgen zemin ve silindir minare duvarından oluşmaktadır. Temeli 5,6 metre derinliğindedir. Zeminin genişliği 3,9x4,1 metre, yüksekliği 5 metredir. Minare yapılırken duvarı 25x25x5 cm büyüklükteki pişmiş tuğla ile düz şekilde yapılmış, dış tarafı desen yapılarak düzgün bir şekilde örülmüştür. Araştırmacılar, Burana'nın batı tarafında mescit olduğunu tahmin etmektedirler. Giriş kapısının yerden 3,5 metre yüksekte tasarlanmış olması nedeniyle minareye, 11-12. yüzyıllarda taşınabilir merdivenle ya da mescidin çatısından girildiği düşünülmektedir. Bilinmeyen bir sebeple Balasagun şehri terk edildikten sonra kule bakımsız kalmış ve çökme noktasına gelmiştir. 19701974 yıllarında B. V. Pomaskin'in projesi ile Kırgız Sovyet Sosyalist Cumhuriyeti Kültür Bakanlığı Özel Bilimsel Restorasyon Atölyesi, Burana'yı kurtarma ve restore etme çalışmalarını yürütmüştür. Beş sene içerisinde minarenin bozulan yerleri baştan sona yeniden tamir edilerek, sekizgen zemini yeniden yapılmıştır. Minareye çıkmak için güney tarafına metal merdiven yerleştirilmiştir (Törökanov, 1989, s. 3-10; Yıldız, 2014, s. 195-202). İnşa tarihindeki şartlar göz önüne alındığında, bütün Çüy Vadisi'ni görebilecek bir yüksekliğe sahip olması nedeniyle hem gözetleme kulesi hem de minare olarak, çok amaçlı kullanıldığı düşünülmektedir. Restorasyon çalışmaları bittikten sonra eski şehir merkezi kompleks olarak Burana Açık Hava Müzesi adıyla ziyarete açılmıştır. Günümüzde kulenin çevresinde; küçük çapta bir müze, Hıristiyan ve Müslüman mezar taşları, balballar ile birlikte türbe, hamam ve kale duvarı kalıntıları bulunmaktadır. Bu kalıntılar bize Balasagun'un tarihteki ihtişamı, önemi ve kültürel zenginliği hakkında önemli bilgiler vermektedir.

\section{2. İstanbul Kız Kulesi}

Roma, Bizans ve Osmanlı'nın başkenti İstanbul'da yer alan Kız Kulesi, İstanbul Boğazı'nın Marmara Denizi'ne yakın kısmında Salacak açıklarında yer alan küçük bir adacık üzerine inşa edilmiştir. İstanbul Boğazı'nda, Üsküdar Sahili'nin 200 metre açıklarında bulunmaktadır. Kız Kulesi, ilk olarak gümrük kontrol noktası olarak kullanılmıştır (Ağalar, 2016, s. 24). "Ne zaman yapıldığı hakkında kesin bir bilgi olmamakla birlikte, bazı kaynaklarda yapılma tarihinin M.Ö. 341 yılına kadar uzandığı görülmektedir." (Sarl, 2016, s. 278) Kız Kulesi'nin eski zamanlardaki isimleri Damalis ve Leandros'dur. İstanbul'un fethi sırasında hasar gören kule daha sonra ahşap olarak inşa edilmiştir. Kaynaklarda küçük kıyamet olarak da nitelendirilen 1509 depreminde ağır hasar görmüş ve Mimar Hayreddin b. Murad tarafından tamir edilmiştir (Türkhan, 2008, s. 659). 1719'da ise ahşap kule çıan yangınla kül olmuş ve 1832

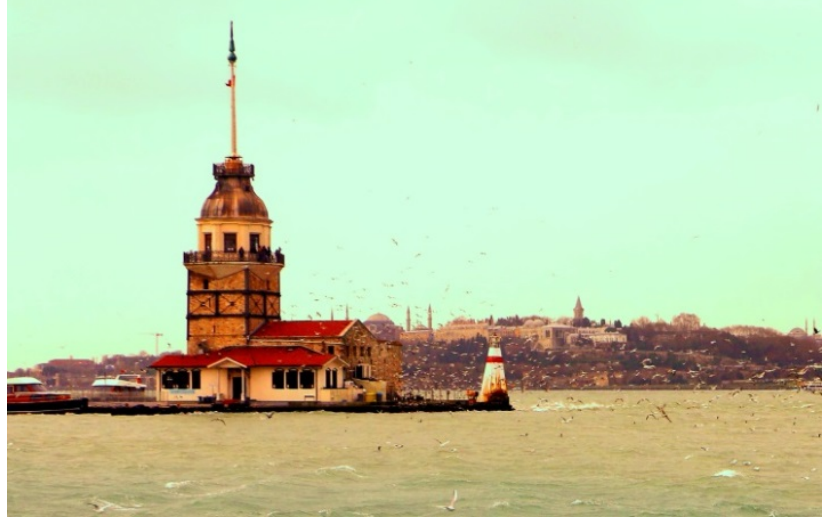

Fotoğraf 2. İstanbul Kız Kulesi, 2016. tarihinde Sultan II. Mahmud Devri'nde günümüzdeki hâlini almıştır. Deniz üzerinde 35-36 metre çapında bir düzlük üzerine oturtulan Kız Kulesi'nin yüksekliği 18 metredir ve kule beş katlıdır. Osmanlı-barok mimari tarzında yapılmıştır. "Mazgallı kalenin kare planlı burcunun tepesinde, pencereli ve etrafı balkonlu bir köşk bulunmaktadır. Bu köşkün üstü dalgalı saçak çıkmasına 
uygun olarak dilimli bir kubbe ile örtülüdür ve ortasında bir bayrak direği yükselir. Kara tarafına bakan kapısının önünde iki sütunun taşıdığı bir revak vardır. Kapının üzerinde ve üçgen bir çerçeve içinde, Hattat Mustafa Rakım Efendi'nin imzasını ve Sultan II. Mahmud'un tuğrasını taşıyan bir kitabe bulunmaktadır. Tuğranın altına 1248 (Miladi: 1832) tarihi yazılmıştır." (T.C. Üsküdar Belediyesi, 2017)

İstanbul Kız Kulesi, tarihin akışı içinde; ticari gemilerden vergi toplama noktası, denizden gelecek tehditlere karşı gözetleme ve savunma kalesi, deniz feneri, önemli kişilerin kapatıldığı hapishane veya sürgün yeri, gümrük istasyonu, top atma ve marş okuma platformu, salgın hastalıklarla mücadele amacıyla kullanılan karantina hastanesi ve radyo istasyonu gibi birçok farklı işlevlerde kullanılmıştır. Özel bir şirket tarafından restore edildikten sonra 2000 yılından beri müze ve restoran olarak işletilmeye devam etmektedir. Sanatsal bir değeri olmasa da, yerinin ve kıyıdan görünüşünün güzelliği sebebiyle İstanbul'un en önemli simgesel yapılarındandır ve dünya çapında bir üne sahiptir. Ressamlara, fotoğrafçılara, şarkıcılara ve sinemacılara ilham kaynağı olmaya devam etmektedir. Oldukça zarif siluetiyle İstanbul'un en önemli simgelerinden biri olan Kız Kulesi, efsaneleriyle de ünlüdür. Ayrıca söz konusu yapıyla hem işlevleri hem de söylenegelen efsaneleri bakımından benzerlik taşıyan Beyşehir Gölü'nde, Silifke'de, Bakü'de ve Azerbaycan'ın muhtelif yerlerinde Kız Kalesi adlı yapılar bulunmaktadır. Efsanelere konu olan iki kule çeşitli özellikleri açısından karşılaştırılmıştır:

Tablo 1. Efsanelerdeki Kulelerin Karşılaştırılması

\begin{tabular}{|l|l|l|}
\hline & \multicolumn{1}{|c|}{ Burana Kulesi } & \multicolumn{1}{c|}{ İstanbul Kız Kulesi } \\
\hline Yapılış Tarihi & 10. yüzyılın ikinci yarısı & M.Ö. 341 \\
\hline Yükseklik & $24,6 \mathrm{~m}$. & $18 \mathrm{~m}$. \\
\hline Şekil & $\begin{array}{l}\text { Sekizgen zemin ve } \\
\text { silindir minare duvarı }\end{array}$ & $\begin{array}{l}\text { Kare planlı mazgallı kale, pencereli ve } \\
\text { etrafı balkonlu bir köşk }\end{array}$ \\
\hline Mimari Tarz & Karahanlı-Türkistan & Osmanlı-barok \\
\hline Tarihteki Konumu & Başkentte & Başkentte \\
\hline Tarihî İşlevi & $\begin{array}{l}\text { Minare, gözetleme } \\
\text { kulesi }\end{array}$ & $\begin{array}{l}\text { Deniz feneri, mezarlık, hapishane, } \\
\text { karantina hastanesi, gözlemevi, vergi } \\
\text { istasyonu, savunma ve gözetleme kulesi }\end{array}$ \\
\hline Günümüzdeki Konumu & Şehir dışı antik kentte & Şehir merkezinde \\
\hline $\begin{array}{l}\text { Günümüzdeki İşlevi ve } \\
\text { Statüsü }\end{array}$ & $\begin{array}{l}\text { Turistik, Devlet } \\
\text { Açıkhava Müzesi }\end{array}$ & Turistik, müze, özel ticari işletme \\
\hline
\end{tabular}

\section{Burana ve İstanbul Kız Kulesi Kaynaklı Ortaya Çıkmış Olan Efsane Varyantları}

Çevrelerinde yaşayan insanların oldukça ilgisini çekmiş olan bu iki mimari eserle ilgili birçok efsane anlatılagelmiştir. İncelememize konu olan efsaneler, iki kule hakkında anlatılanlar içerisinde en yaygın ve birbirlerine en yakın olan varyantlardır.

\subsection{Burana Kulesi Efsanesi}

Kudretli hanın dünyada her şeyden çok sevdiği güzel kızı yavaş yavaş büyümektedir. Han yaşlıdır ve hanbikenin (han kızı) mutluluğunu görmeden öleceğinden korkar. Bir gün bahşıları (şaman, kam, kâhin) çağırır ve kızının geleceği hakkında bilgi vermelerini emreder. Bahşılar (Kırgız Türkçesi: bakşı), uzun uzun konuşurlar ve sonuçta dünyada kimsenin hanbike kadar mutlu olamayacağını söylerler. Fakat bahşıların arasından en yaşlısı: Ey yüce hükümdar! İstersen beni cezalandır, fakat acı gerçeği sonuna kadar dinle. Kızının kaderi çok acı. O ergenlik çă̆ına girdikten sonra bir karadul örümceğinin 
ısırmasından ölecek, der. Han korkutucu bakışlarla ona doğru bakar, fakat bahşı dediğinden dönmez. Han; öyle bir kule yapın ki göğe değsin, altına da derin bir zindan yapıp bahşıyı oraya atın, der. Hanbike kulenin tepesindeki küçük, aydınlık odada yaşamaya başlar. Hizmetçiler dik merdivenlerden ona yiyecek getirirler, yiyecek veya giyecekler içerisinde zehirli karadul örümceği var mı diye de üç defa elden geçirirler. Zaman akıp gider ve hanbike on altı yaşın doldurur. Çiçek gibi açılır, sabah çiyleri gibi tazedir. Han, hayır kehanet gerçekleşmeyecek, diye düşünür ve kızını kutlamak için yanına gider. Kızına büyükçe bir tepsiyle sarı üzüm getirir. Hanbike üzümlere uzanıp en büyük salkımı alır ve o anda bir çı̆̆llk atar ve onu salkımın arasına saklanmış olan karadul örümceği ısırır. Yaşlı han ölen kızının acısına dayanamaz ve kendisi de o yıl ölür (Brudny \& Eşmambetov, 1977, s. 291-292; Kambaralieva, 2015, s. 174).

\section{2. İstanbul Kız Kulesi Efsanesi}

19. yüzyılda İstanbul Folkloru adlı bir kitap kaleme alan Carnoy ve Nicolaides adlı Fransız araştırmacıların da incelediği halk arasında Yılanlı Hikâye olarak anılan efsane varyantı şu şekildedir:

Bizans krallarından birinin çok sevdiği ve üzerinde titrediği bir kızı vardır. Bir gün kâhinlerini toplar ve onlara kızının istikbalini sorar. Imparator kâhinlerinden biri ona, kızının on sekiz yaşına bastığında yılan tarafından sokularak öleceğini söyler. Kral, bu acı olayı engellemek için kule inşa ettirir ve kızını buraya kapatarak muhafaza altına aldırır. Kuleye bir yılanın girmesini engelleyecek her türlü önlemi almıştır. Günlerden bir gün kralın kızı hastalanır, ateşlenir ve yataklara düşer. Bunun üzerine tüm hekimler seferber olur, ancak çare bulamazlar. En sonunda bir hekim, kralın kızını iyileştirmeyi başarır. Kral o günü bayram ilan ederek kutlamalar yapar, törenlerin ardı arkası kesilmez. Bu sırada kuledeki kraliçeye de bir üzüm sepeti gönderilir. Bu sepetin içinden küçük bir yılan çıkar, prensesi sokar ve kâhinin sözleri gerçekleşmiş olur. Kralın kızı ölür ve kral ona Ayasofya'nın üzerinde bir tabut yapttrir. Bir rivayete göre, efsanedeki kral 578-582 tarihleri arasında hüküm sürmüş olan Bizans Imparatoru II. Konstantin'dir (Carnoy \& Nicolaides, 1894, s. 41-46'dan aktaran Baykara, 2004, s. 334-335; Tatar, 2012, s. 1820; T.C. Üsküdar Belediyesi, 2017).

Gizemli bir yapı olan Kız Kulesi ile ilgili tabii olarak daha birçok efsane anlatılagelmektedir. Bunlardan bazılarının araştırmamıza konu olan varyantın daha sağlıklı olarak değerlendirilmesi açısından göz önüne alınması uygun olacaktır.

1. 1611 yılında İstanbul'a gelen Domenico Gierosolimitano, Kız Kulesi'nden de söz ederken şu rivayeti aktarmıştır: Diyorlar ki burasını eski bir imparatorun kızı yaptı, burada yaşadı ve bakire olarak öldü. Şimdi dört asker üç topla orada kalıyorlar ve devamlı nöbet tutuyorlar (Michele Bernardini, 1985, s. 17-38'den aktaran Baykara, 2004, s. 332).

2. Roma Dönemi'nde Ovidius tarafından kaydedilmiş, İngiliz şair ve yazar Christopher Marlowe tarafından ise genişletilerek nazım şeklinde anlatılmış olan ve Kız Kulesi'ne atfedilen efsane ise kısaca şöyledir:

Hero, Afrodit Tapınă̆ı'na bağh bir rahibeymiş ve aşk onun için yasakmış. Kız Kulesi'nde yaşayan Hero' ya âşık olan Leandros, her gece yüzerek adaya gelir, ona aşkını fisıldarmış. Gece karanlı̆̆ında güzel rahibenin yaktı̆̆ı ateş Leandros'a yol gösterirmiş. Ancak, firtınalı bir gecede rüzgâr meşaleyi söndürmüş ve Leandros yolunu yitirerek karanlık sularda boğulmuş. Bunu öğrenen Hero da kendisini Boğaziçi'nin soğuk sularma atıvermiş... (1598)

3. Evliya Çelebi'nin (XVII. yüzyıl) aktardığı efsane ise şöyledir:

Bizanshlar, Battal Gazi'nin korkusundan deniz yüzünde büyük bir kule yaptırı Üsküdar tekfurunun kızını ve kıymetli eşyaları saklar. O kuleye Kız Kulesi anlamında "Pirgos Tiskuris" derlermiş. Bu sırada Battal Gazi, Şam fethini bitirerek Üsküdar'ın böyle tahkim edildiğini işitince, yanına 
aldı̆̆̊ gazilerle Üsküdar'ı basar. Oradan kayıkla Kız Kulesi'ne geçip kralın kızını, hazinesini ve ötekileri alı Üsküdar'a geçer. Ancak Üsküdar'a zarar vermeksizin, geriye, Medayin'e (İran'da) döner (Akkaya, 2017, s. 325; Baykara, s. 332-333).

"Hero ile Leandros" Roma ve Bizans dönemlerinde Anadolu'da, Mısır'da ve Kırım'da söylenmiştir. Önceleri öykünün tek kaynağının Yunan mitolojisi olduğu düşünülse de artık Anadolu ve Orta Doğu anlatılarından etkilenmiş olduğu ortaya çıkmıştır. Batı Avrupa'daki Yunan hayranlığı sebebiyle Yunan ruh ve düşünce yapısının her türlü yaratmanın temelinde bulunduğuna inanılmış ve her şey bu kültüre mâl edilmek istenmiştir. Ancak yirminci asrın ikinci çeyreğinde yapılmaya başlanan araştırmalar; Yunan mitolojisi ve felsefesinin beslendiği ana kaynakların Anadolu, Ortadoğu ve Mısır havzası olduğunu ortaya çıkarmıştır (Yörükân, 2006, s. 120-128).

\subsection{Burana ve İstanbul Kız Kuleleri Kaynaklı Ortaya Çıkmış Olan Efsanelerin} Karşılaştırılması

Rus halkbilimci Vladimir Propp 1928 yılında yayımladığı Masalın Biçimbilimi (Morfologiya Skazki) adlı çalışmasında olağanüstü masalları yapı bakımından inceleyerek metin merkezli yapısal çözümleme yöntemini geliştirmiştir. Propp'a göre masalları muhteva ölçütlerine göre sınıflandırmak yanlıştır. Masalda değişmez değerlerle değişken değerlere rastlanmaktadır. Değişken unsurlar kişi adları, aynı zamanda kişilerin nitelikleri ve çevredir; değişmez unsurlar ise kişilerin eylemleri ya da işlevleridir. Buradan masalın çoğunlukla aynı eylemleri değişik kişilere yaptırttığı sonucu çıkarılabilir. Bu da masalları kişilerin işlevlerinden kalkarak incelememizi sağlamaktadır. Kişilerin işlevleri masalın temel bölümlerini göstermektedir ve öncelikle ayırt etmemiz gerekenler de bu işlevlerdir (1985, s. 26-27). Halk edebiyatının en yaygın kullanılan türlerinden olan efsaneler; mit, destan ve masallarla sınırdaştır. Kısa, nesirle anlatılmıs, doğaüstü olay ve tiplere sahip olmaları sebebiyle en çok masalarla benzerlik göstermektedir. Ancak hiç bir olağanüstü yanı bulunmayan efsanelerle de karşılaşmak mümkündür. Masallarda genellikle mekân ve zaman belirsizken efsaneler, zamana ve mekâna bağlı bir anlatı türüdür. Efsanelerin hacim, şekil ve tip bakımından masallarla benzerlik gösterdiğinden dolayı; Propp'un masalların yapısal çözümleme yönteminde (morfolojik yöntem) uyguladığı gibi efsanelerin de aynı şekilde değişmez ve değişkenleri esas alarak değerlendirebiliriz.

Burana ve İstanbul Kız kuleleri üzerine söylenegelen efsanelerindeki şahıs kadrosu ve olay örgüsü şaşırtıcı derecede benzemektedir. İki efsanede de merkezi kahramanlar soylu bir aileye mensuptur. Şahıs kadroları genel olarak aynı olmakla birlikte Burana'daki baba han, kız hanbikedir; Kız Kulesi'ndeki baba kral, kız prensestir. Falcı ise Burana'da bahşı, Kız Kulesi'nde kâhin olarak geçmektedir. Bu bölgesel ve tarihî sebeplerden kaynaklanmaktadır. Burana Karahanlı Dönemi'nde yapıldığı ve bu bölgede genellikle Türk soylu hükümdarlık ve hanlıklarının hüküm sürdüğü için tiplerdeki adlandırmalar da yerel adlandırmalara göre şekillenmiştir. Burana üzerine söylenen efsane; bölgenin Karahanlılardan sonra Türk ve Moğol boyları arasında sürekli el değiştirmesiyle, yeni sakinleri tarafından Balasagun şehrinin eski sakinlerine atfedilmiştir. İstanbul'un 1543 yılında Osmanlı Devleti tarafından fethedildiği göz önüne alınırsa mevcut olan Kız Kulesi ile ilgili ortaya çıan efsane, Türkler tarafından daha önce hüküm sürmüss olan Bizans'a atfedilmiştir. Böylece kral ve prenses tip adlandırması ortaya çıkmıştır. Ayrıca İstanbul'daki efsaneye Bizans bakiyesi Hıristiyan Rum halkın da katkıda bulunmuş olma olasılığı yüksektir. İki efsanede bölgeye sonradan gelmiş veya bölgede yaşayıp da bu binaların mazisini bilme ve anlamlandırma çabasında olan toplumlar tarafından yaratılmıştır. İki efsanede de ortak kadın, yönetici/hükümdar, şifacı/bilge/aksakal ve hayvan 
tipleri vardır. İki efsanenin de merkezi kahramanları asilzade kadınlar ve koruyucu babalardır. Kızların ölümüne sebep olan Burana'da karadul örümceği, Kız Kulesi'nde yılandır. Bu farklılık çevreyle ilgili şartlardan kaynaklanmaktadır. Çünkü Burana Kulesi karada, İstanbul Kız Kulesi denizdedir. Neticede iki efsanede de korkutucu, endişe verici ve zararlı bir tip olarak zehirli hayvanlar yer almaktadir.

Olay örgülerindeki farklı noktalar şunlardır: Burana Efsanesi'nde İstanbul Kız Kulesi Efsanesi'nden farklı olarak, kâhin cezalandırılmıştır ve mağdur konumundadır. İstanbul'daki efsanede Burana'dan farklı olarak kız ölmeden hemen önce hastalanmış ve iyileşmiştir. Kız, daha sonra yapılan kutlamalarda hediye olarak gelen bir üzüm sepetindeki yılanın sokmasıyla; Burana'da ise babanın kızına kendi eliyle getirdiği üzüm sepetindeki karadul örümceğinin sokması sonucu ölmüştür. İstanbul'daki efsanede üzüm sepetinin başka birileri tarafından gönderilmiş olması, yaşanılan kozmopolit sosyal çevrenin folklora yansıması olsa gerektir. Efsanelerin içeriği; Türk kültüründe kız çocuğuna verilen değeri, onu korumak için yapılabilecek fedakârlıkları ve aile bağlarını gösterir niteliktedir. Efsanelere konu olan iki kule de bir kızı tehlikeden koruma amacıyla yaptırılmıştır. Hatta İstanbul Kız Kulesi'nin ismi de doğrudan bir kadına atfedilmiştir. İki efsane de kötü sonla bitmektedir. Burana'daki efsanede baba Kız Kulesi'ndekinden farklı olarak evlat acısına dayanamayarak ölür. Güçlü han ve kral, halklarına ve dünyaya hükmetseler bile kızlarının başlarına gelecek olanlara engel olamazlar. Efsanelerin ikisinde de ölümden, alınyazısından kaçlamayacağı ve kaderin önüne geçilemeyeceği ana fikri hâkimdir.

Elde ettiğimiz bilgiler ışığında, bu iki efsanedeki kahramanlar tipolojik ve karakter özellikleri açısından tablo şeklinde karşılaştırılmıştır:

Tablo 2. Efsanelerde Geçen Kahramanların Tipolojik ve Karakter Özellikleri Açısından Karşılaştırılması

\begin{tabular}{|l|l|l|}
\hline Tipler & Burana Kulesi & İstanbul Kız Kulesi \\
\hline Kadın & Hanbike: kız evlat & Prenses: kız evlat \\
\hline Yönetici/hükümdar & Han: baba, koruyucu & Kral: baba, koruyucu \\
\hline Şifacı/ermiş/aksakal & Bahşı: esrarengiz, mağdur & Kâhin: esrarengiz \\
\hline Hayvan & Karadul örümceği: zararlı & Yılan: zararlı \\
\hline
\end{tabular}

Burana ve İstanbul Kız kuleleri efsanelerindeki bu olağanüstü benzerlik 31 Ekim 1884'te Kazan'da gerçekleştirilen Rusya IV. Arkeoloji Çalışmaları Zirvesi'nde de araştırmacıların ilgisini çekmiştir (31-Oktyabr': Tarıh Baraktarı, 2007). Bahsi geçen iki kule de halk nazarında şekilleri itibariyle korunaklı bir yeridir ve bir hükümdar kızını tehlikeden koruma amacıyla inşa edilmiştir. Ayrıca Azerbaycan'daki Bakü Kız Kulesi Efsanesi'nde zalim bir hanın oğluna almak istediği kızın erkek kardeşleri onu korumak için kule inşa ettirmişlerdir (Acaloğlu-Beydili 2005: 168-169). Silifke Kız Kalesi Efsanesi'nde ${ }^{1}$ bölgenin beyi, Beyşehir Kız Kalesi Efsanesi'nde de bir Selçuklu Sultanı Burana ve İstanbul Kız kulelerindeki efsanelerdeki gibi kızlarını zehirli bir hayvandan korumak için söz konusu yapıları inşa ettirmişlerdir. Bu efsanelerde gelişen olaylar Türk Dünyasının her yerinde kadının toplumdaki önemi ve statüsü konusunda önemli ipuçları vermektedir.

Burana Efsanesi'nde geçen bahşı kelimesini eski Türk inançları çerçevesinde değerlendirmek gerekmektedir. Bahşı kelimesi Burkancılıktaki (Türk Budizmi) din adamı anlamına gelen sözcükten gelmektedir. Rus etnograflar tarafından Türkistan'da yapılan araştırmalara göre 20. yüzyılın başlarında bile bahşılar, İslam dininin ağır baskısı altında varlıklarını muhafaza

1 Ayrıntılı bilgi için Sakaoğlu 1976: 151-152. 
edebilen gerçek kamlardır (şaman), tespitinde bulunulmuştur (İnan, 1986, s. 112). Eski anlamını, önemini ve değerini kaybetmiş olsa da günümüzde bahşılık geleneği yaşamaktadır. Günümüz Kırgızistan'ında da bahşılar tıpkı eski Türk kamları gibi kâhin (falcı), şifacı (halk hekimi), yadacı $^{2}$ veya belirli çevrelerce itibar edilen bir din adamı statüsündedir. 21. yüzyılın şartları gereği tabii olarak toplumun bahşılara bakış açısı kişiden kişiye ve bölgeden bölgeye değişmektedir.

1797'de İstanbul'da bulunan A. L. Castellan, Kız Kulesi'ne dair Türkler arasında söylenen efsanenin Fransızca geniş bir çevirisini vermiştir. Efsanede "Mihir-Schighil" (Mihr-i Çiğil / Çiğil Güneşi) adını verdiği, bir padişah kızının hikâyesini anlatır. Hikâyeye, buraya gelen bir İranlı Şehzade de karışır. Bu varyantta kulede yaşayan kıza verilen Mihr-i Çiğil adı dikkat çekmektedir. Castellan bu kelimenin anlamını "güzellik güneşi" (soleil des beaute) olarak vermiştir. Ancak burada söz konusu olan "çiğil" İran ve erken devir Türk edebiyatında güzellik simgesi sayılan "çigil" sözcügüuür. Üsküdar'da Türkler arasında söylenen efsanelerden birisi, eski Karahanlı devrinden kalmış olan hatıraları da yansıtmaktadır (Baykara, 2004, s. 333). Kaşgarlı Mahmud'un ve çeşitli yabancı seyyahların naklettiğine göre Karahanlılar Dönemi'nde Taraz, Balasagun, Isıkgöl ve Kaşgar ahalisinin ekseriyetle Çiğillerden (Çiğil Türkleri) oluştuğu bilgisi bize mesele hakkında ipuçları vermektedir (Minorsky, 1937, s. 297-300; Barthold, 2010, s. 70, 96, 349). Castellean'ın aktardığı Mihr-i Çiğil adını da irdelemek gerekir. Çiğiller çevrelerinde, şehirlerinin ve kendilerinin güzellikleriyle tanınan bir Türk kavmi olarak bilinmekteydi (Güftar \& Ziya, 1984, s. 714). Orta Farsçadaki ve Eski Türk Edebiyatı'ndaki “bir güzellik timsali" olarak "çigil" kelimesi muhtemelen bu kavim kaynaklı ortaya çıkmıştır. Fransız seyyahın aktardığı efsanedeki Mihr-i Çiğil adlı kahramanın ismini değerlendirirken eski edebiyattaki anlamının yanı sıra büyük olasılıkla Burana Kulesi'ni inşa etmiş ve efsanesini de üretmiş olan Çiğil Türklerini de göz önüne almak gerekmektedir. Çiğil Türklerinin bir kısmı Karahanlıların yıkılması, Türkistan'daki siyasal istikrarsızlık ve Moğol baskınları nedeniyle göç ederek Anadolu'da muhtelif yerlere yerleştirilmişlerdir. Günümüzde de Anadolu'da Çiğil adını taşıyan birçok yerleşim yeri vardır. ${ }^{3}$

Halkbiliminde yayılma kuramının öncülerinden Friedrich Ratzel'e göre kültürel ürünlerdeki benzerlikler bu toplumlar arasındaki tarihsel bir ilişkiyle ilgilidir. Benzerliğin temelinde, insanlık tarihinde tespit edilen ve edilemeyen birçok göç vardır. Bu göçlerle insanlar, oluşturdukları kültürel yapıları da beraberlerinde taşımaktadırlar (Örnek, 1968, s. 173). Ratzel'in öğrencisi Leo Frobenius ise eski devirlerden beri dünyada on iki kültür yaratma çevresi olduğunu ve bu çevrelerden kültürün yayıldığını öne sürmüştür. Frobenius'un on iki kültür çevresinden birisi de Bozkır Kültür Çevresidir. Bu görüşe göre Türkler, dünya kültürünün temellerinde var olan kültürel ürünlerin ilk şekillerini yaratan toplumlardan birisidir (Kafesoğlu, 1998, s. 36-38). Bunun sonucunda farklı Türk topluluklarında benzer efsanelerin karşımıza çıkması tabiidir. Finli halkbilimci Honko'ya göre efsaneler inançları açıklamaktadır ve efsanelerin sınıflandırmasını yapıldığında onları mahalli ve gezgin efsaneler olarak ikiye ayırmak mümkündür (Petikainen, 2003, s. 224). İki kulenin efsanelerindeki şaşırtıcı benzerlik Türklerin Balasagun'dan giderken millî hafıza olan efsanelerini de yeni vatanlarına götürdükleri ihtimalini güçlendirmektedir.

Türk kavimlerinde çok eski devirlerden beri yaygın bir inanca göre, büyük Türk Tanrısı Türklerin atasına "yada" denilen bir sihirli taş armağan etmiştir. Sahibi bununla istediği zaman yağmur, kar, dolu yağdırır ve fırtına çıkarırdı. Bu taş her devirde Türk kamlarının ve büyük Türk komutanlarının ellerinde bulunmuştur. Zamanımızda da büyük kamların ve yadacıların ellerinde bulunmaktadır (İnan, 1986, s. 160).

3 Ayrıntılı bilgi için Yakupoğlu 2010: 126-130; Sezen 2006: 129. 


\section{Sonuç}

Burana Kulesi, Türkistan'ın merkezi sayılabilecek bir konuma sahip olan Kırgızistan'da, Kız Kulesi ise Asya ile Avrupa'nın kesiştiği noktada yer alan Türkiye'nin İstanbul şehrinde bulunmaktadır. İki kule de bulunduğu ülke için marka değerine ve turizm açısından çok önemli işlevlere sahiptir. İki kule arasındaki kuş uçuşu mesafe 3.785 kilometredir. Coğrafi uzaklık ve tarihsel şartlar sebebiyle iki coğrafya arasında siyasal, sosyal ve kültürel ilişkiler günümüzdeki kadar canlı olmamıştır. İncelediğimiz efsanelerde değişkenlerde (kişi adları, kişilerin nitelikleri ve çevre) kısmen farklılıklar olsa da değişmeyenlerin (kişilerin eylemleri ya da işlevleri) ortak olduğu sonucu ortaya çıkmaktadır. Yüzyıllardır birbirinden uzakta, farklı tarihî süreçlerden geçmiş ve farklı komşularla kültür alışverişinde bulunmuş olmalarına rağmen, Kırgızistan ve Türkiye Türklerinin söz konusu efsaneleri içerik, olay örgüsü ve şahıs kadrosu bakımından büyük benzerlikler göstermektedir. Bu iki efsane varyantındaki benzerlikler ancak genetik ortaklıkla ve kültürel kalıtımla açıklanabilir. Bu benzerlikler, anayurtlarından sözlü geleneğin ve mitolojik öğelerin yeni yurtlara tek bir merkezden taşınmış olma ihtimalini güçlendirmekte; farklılıkların ise yaşanan coğrafyalardan, geçirilen farklı tarihî süreçlerden ve komşularla etkileşimden kaynaklandığı görülmektedir.

Araştırmamıza konu olan iki mimari eser de halk nazarında bir genç kızın korunduğu ulaşılmaz, heybetli ve emniyetli bir yerdir. İncelediğimiz Kız Kulesi Efsanesi varyantının çeşitli araştırmacılar tarafından Bizans kaynaklı olduğu öne sürülmekle birlikte çalışmamızda bu değerlendirmelerin Propp'un bahsettiği değişken unsurlara dayandırıldığ 1 tespit edilmiştir. Efsanede geçen kişi adları, aynı zamanda kişilerin nitelikleri ve çevreye bağlı olarak efsanenin menşei ve kaynağı konusunda ortaya konulan görüşler yanılgıya sebep olmuştur. İstanbul $\mathrm{K} \imath z$ Kulesi Efsanesi her ne kadar Bizans kaynaklı adlandırmalar barındırıyor ve efsanede Bizans Dönemi'ne atfediliyor olsa da bu efsane varyantının konu, olay örgüsü, kişilerin eylemleri ve işlevleri noktasında Burana Kulesi Efsanesi'yle neredeyse bire bir örtüşmesi sebebiyle gezgin bir efsanedir ve kaynağının Türkistan olma ihtimali daha ağır basmaktadır. Beyşehir'de Selçuklu, Silifke'de Beylikler, Azerbaycan'da Şirvanşahlar ve Kırgızistan'da Karahanlılar Dönemi'ne atfedilen, benzer muhtevalara sahip, bölgenin yöneticisi tarafından kızını tehlikeden korumak üzere inşa edilmiş olan yapılar çevresinde ortaya çıkan efsanelerle de karşılaşmamız efsanenin Türk göçleriyle paralel olarak doğudan batıya taşındığını göstermektedir. Nitekim Türk destanlarında da kızlarını korumak üzere Hakan'ın kızlarını kule yaptırıp oraya kapatması motifi bulunmaktadır. İstanbul'un 1453 yılında fethedilmesiyle şehrin yeni sakinleri olan Türklerin, şehirdeki mevcut yapıların oluşum hadiseleriyle ilgili bir yorumlama ve anlamlandırma çabasına girmiş oldukları görülmektedir. İstanbul'a yerleşen ilk Türkler yapıların mazisini yorumlarken olaylardaki şahısları Kız Kulesi Efsanesi'nde olduğu gibi tabii olarak şehrin eski sakinlerine dayandırmışlardır. Böylece Burana'daki efsane İstanbul'a ulaştı̆̆ında; han Bizans imparatoruna, hanbike prensese, bahşı kâhine, karadul örümceği ise yılana dönüşmüştür. Mekânın mazisi konusundaki muamma efsaneyle anlamlandırılırken ana kaynaktan taşınan efsanenin olay örgüsü, konusu, inanç ve kültür unsurları korunmuş, böylece mekâna milli bir kimlik kazandırılmıştır. Ayrıca Kız Kulesi ile ilgili Bizans kaynaklı efsanelerin konuları, olay örgüleri ve şahıs kadroları bakımından referans kaynağın eski Yunan mitolojisi olması ve incelenen efsane varyantıyla belirgin bir benzerlik göstermemesi de bu görüşü destekler niteliktedir. Neticede iki efsanenin Türkistan ana kaynağından çıkmış olma olasılığı yüksektir. Türkiye Türkleri göç ettikleri anayurtlarındaki inanç, kültür ve mistik unsurları da beraberlerinde getirmiş ve yeni yurtlarındaki bir yapıya atfetmişlerdir. Türkler kendi inanç, zevk, hayal güçleriyle ürettikleri bir efsaneyi Kız Kulesi için yeniden yorumlayarak anlatmaya 
devam etmişlerdir. Efsanedeki paralellikler Türk halklarının, yüzyıllar süren göçlere ve binlerce kilometrelik uzaklığa rağmen folklorik olarak aynı kaynaktan beslendiklerinin ve aynı değerleri yaşattıklarının kanıtıdır.

Yaptığımız incelemede efsanelerin oluşumuna kaynaklık eden yapıların bulundukları çevre için; çok büyük mimari, kültürel ve folklorik değer taşıdıkları görülmektedir. Modernleşme ve kentleşmenin etkisiyle tarihî yapılar ve bunların çevrelerinde oluşan efsaneler de yok olma tehlikesiyle karşı karşıyadır. Bu yapıların ruhu ve kimliği olan efsanelerin kayıt altına alınarak kültürel belleğin korunması, gelecek kuşaklara aktarılması ve sağlıklı efsane varyantlarının belirlenerek turizm ve tanıtım faaliyetleri içerisinde de değerlendirilmesi gerekmektedir. Burana Kulesi'nin içinde bulunduğu Balasagun Antik Kenti'nin koruma ve tanitma faaliyetlerindeki yetersizlikler nedeniyle hak ettiği değeri görmediği açıktır. Türkiye'nin ve İstanbul'un markası ve sembollerinden olan Kız Kulesi'nin özel ticari bir işletme olarak kullanılması yerine bir dünya mirası, kültür ve sanat varlığı olarak değerlendirilmesi daha uygun olacaktır. Türk Keneşi ve TÜRKSOY gibi kuruluşlar tarafından tıpkı UNESCO Dünya Miras Listesi gibi "Türk Dünyası Doğal ve Kültürel Miras Listesi" oluşturularak bu tür yapıların kayıt altına alınması, restorasyonu, korunması ve dünya turizmine kazandırılması gerekmektedir. Bu sayede mekânın kimliği olan yapılar hem korunmuş hem de sosyal, kültürel ve ekonomik hayata daha verimli bir şekilde kazandırılmış olacaktır.

\section{Summary}

Burana is used as the name of an ancient city, $12 \mathrm{~km}$ southwest of Tokmok district center, $81 \mathrm{~km}$ from Bishkek, the capital of Kyrgyzstan. These ruins, called Burana, are actually Balasagun, the capital of Turgish (699-766), Karluks (766-840) and Kara-Khanid Khanate (8401212). The Burana Tower was built in the first half of the 11th century. The height of the tower is 24 meters. It was used both as a minaret and as a watchtower. Today, there are a small museum, Christian and Muslim tombstones, türbe (mausoleum) with the balbals (kurgan stelas), hamam (Turkish bath) and the ruins of the defensive wall around the tower.

The Maiden's Tower is a tower lying on a small islet located at the southern entrance of the Bosphorus from the coast of Üsküdar in Istanbul, Turkey. The tower, which is placed on a flat surface of 35-36 meters in diameter, is 18 meters high and has five floors. The Istanbul Maiden's Tower was used in various functions: as a watchtower, as a defensive tower, as a lighthouse, as a prison and a place of exile, as a customs station, as a platform for cannon fire and also reading marches, as a quarantine hospital and a radio station. Due to its location and beautiful landscape, which opens from the shore, the tower is one of the most important sights of Istanbul and has worldwide popularity.

Khan has a beautiful daughter whom he loves more than anything else. Old khan is afraid that he will die without seeing the happiness of hanbike (daughter of Khan). He calls the bakshies (soothsayers) and orders them to tell about the future of his daughter. Bakshies told that hanbike would be the happiest in the world. But the oldest of them said that the fate of hanbike would be very sad and she would die from the bite of a spider before reaching adulthood. The bakshy was cast into prison. Khan ordered to build a very high tower. From that moment hanbike began to live in a small bright room on top of the tower.

Hanbike is sixteen years old, khan thinks that the prophecy will not come true, and goes to her with gifts. He brings a big tray of grapes to his daughter. At this moment a spider crawls out of the grapes and bites the hanbike. Hanbike dies. Old Khan is very upset by the death of his daughter and dies same year.

One of the Byzantine kings has a daughter whom he loves very much. One day, he 
gathered the soothsayers and asked them about the future of his daughter. One of them told him that his daughter would be stung by a snake at the age of eighteen. To prevent this sad event, the king built a tower and locked his daughter there. King took every precaution. One day the king's daughter became very ill. All the doctors of the kingdom tried to find a cure. Finally, one doctor managed to cure the king's daughter. The king celebrated this day as a holiday. A basket of grapes was sent to the princess. At this moment a small snake crawled out of the basket and stung the princess. The words of the soothsayer came true and the princess died.

The characters and plot in the aforementioned legends are very similar. The main characters belong to a noble family. The father in the legend of Burana is the khan, and his daughter is hanbike. In the legend of the Maiden's Tower, the father is the king, and the daughter is the princess, a bakshy is in Burana and a soothsayer is in the Maiden's Tower. This is due to regional and historical reasons.

In both legends there are noble women, fathers-rulers, soothsayers, bakshies, healers, saints and venomous, fear-giving animals. The black spider is the cause of the death of the hanbike in Burana, the snake - in the Maiden's Tower. This difference is due to environmental conditions, because the tower of Burana is on land, the Maiden's Tower is at sea.

Legends tell about values and family ties in the Turkic culture. Also legends have the bad ending. The mighty khan and the king cannot change the fate, despite the fact that they rule the people and the world. In both legends, the main idea is that you cannot avoid the death and escape from the fate.

Both towers have brand value and very important features in terms of tourism for the country where they are located. In the legends that are researched, the environment, the names and the qualifications of people, have some differences, but the actions and functions are common.

The similarities in the legends of two Turkic people, which are geographically distant from each other, experienced different historical processes with different political boundaries and living conditions, can only be explained by a genetic community and cultural heritage. These similarities reinforce the possibility that oral traditions and mythological elements from their homeland were moved to new places of residence. The differences are associated with the new geographical location, different historical processes and interactions with neighbors.

Legends have great architectural, cultural and folklore value. Under the influence of modernization and urbanization, the legends are endangered. Legends that are the soul and originality of architectural structures should be recorded, and cultural memory should be preserved, passed on to future generations, and versions of legends should be evaluated in the framework of tourism and promotional activities. 


\section{KAYNAKÇA}

Acaloğlu, A. \& Beydili, C. (2005). Osatirler, afsanə və revayətler. Bakü: Şərq Qerb.

Ağalar, N. (2016). Galata Kulesi ve Kız Kulesi'nin aşkı (Yüksek lisans tezi). Erişim adresi: https://tez.yok.gov.tr/UlusalTezMerkezi/giris.jsp

Akkaya, M. (2017). Evliya Çelebinin Seyahatnamesi'nde Üsküdar. Kesit Akademi Dergisi (The Journal of Kesit Academy), (3) 11: 321-338. doi: 10.18020/kesit.1330.

Asanov, Ü. (2004). Kırgızstandın geografyası. Bişkek: Mamlekettik Til cana Entsiklopediya Borboru.

Bartold, V. (2004). Orta Asya Türk tarihi dersleri (H. Dağ Haz.). İstanbul: Çağlar Yay.

Bartold, V. (2010). Orta Asya tarih ve uygarlı (D. A. Batur Çev.). İstanbul: Selenge Yay.

Baykara, T. (2004), Türkistan'dan gelen bir isim ve efsane: Kız Kulesi. I. Üsküdar Sempozyumu içinde (s. 332-336). İstanbul: Üsküdar Belediye Başkanlığı Üsküdar Araştırmaları Merkezi.

Buyar, C. (2017). İlk Türk-İslam şehirlerinden biri olarak Balasagun. A. Demir (Ed.) Türk Tarihine Dair Yazılar içinde (547-566). Ankara: Gece Kitaplı̆̆ı.

Brudnıy, D. \& Eşmambetov, K. (1977). Kirgizskie narodnıye skazki. Frunze: Kırgızstan.

Carnoy, H. \& Nicolaidès, J. (1894). Folklor de Constintinople. Paris.

Esin, E. (1978). İslamiyetten önceki Türk kültür târihi ve İslâma giriş. İstanbul: Edebiyat Fakültesi Matbaası.

Fedakar, P. (2013). Evliya Çelebi'nin izinde İzmir'in imgeleri. Kent ve Seyyah: Evliya Çelebi'nin Gözüyle İzmir ve Çevresi-II içinde (s. 229-236). İzmir: Ege Üniversitesi Basımevi.

Güftar, G. \& Ziya, F. (1984). Farsça-Türkçe lûgat. İstanbul: Millî Eğitim Basımevi.

Güner, İ. \& Ertürk, M. (2004). Türkiye il merkezi kent adlarının kaynakları üzerine bir araştırma. Muğla Üniversitesi SBE Dergisi, Bahar (12), 39-62.

Hacaloğlu, Y. \& Memişoğlu, R. (2010). Dede Korkut destanlarında adları geçen Oğuz beylerinin hatıralarını taşıyan yer adları üzerine bir deneme. Journal of Social Policy Conferences, Ekim (49), 771-815. Erişim adresi: https://dergipark.org.tr/tr/pub/iusskd/issue/897/10046.

İnan, A. (1986). Tarihte ve bugün Şamanizm. Ankara: Türk Tarih Kurumu Basımevi.

Kafesoğlu, İ. (1998). Türk millî kültürü. İstanbul: Ötüken Neşriyat.

Kambaralıeva, U. (2015). Eldik ulamıştar cana ikayalar körköm çıgarmalarda cana filmderde. Bişkek: Kırgızça Süylöşölü.

Kanimetov, A. \& Esenalieva, G. (2014). Karahaniler dinastiyasının kelip çıgışı. İzvestiya Vuzov (4), $107-$ 109.

Marloe, C. (1598). Hero and Leander. London: Adam Islip.

Minorsky, V. (1937). Hudîd al-âlam-the regions of the world. Londra: Oxford University Press.

Örnek, S. V. (1968). Etnolojinin tarihçesi, başlica ekolleri, görevleri. Antropoloji (4), 165-193. Erişim adresi: $\quad$ http://sedatveyisornek.humanity.ankara.edu.tr/files/2014/12/1968-EtnolojininTarihcesi.pdf.

Petikainen, J. (2003). Efsanenin yapısı ve fonksiyonu (İ. Görkem Çev.). G. Ö. Eker \& M. Ekici \& M. Ö. Oğuz \& N. Özdemir (Haz.) Halkbiliminde Kuramlar ve Yaklaşımlar içinde (s. 223-240). Ankara: Milli Folklor Yayınları.

Propp, V. (1985). Masalın biçim bilimi (M. Rifat \& S. Rifat Çev.). İstanbul: Kent Basımevi.

Sakaoğlu, S. (1976). 101 Anadolu efsanesi. İstanbul: Damla Yayınevi.

Sarı, E. (2016). Efsaneler. Antalya: Nokta E-book Publishing. Erişim adresi: https://books.google.kg/books?id=THnbDQAAQBAJ\&printsec=frontcover\&dq=eren+sar\%C4\%B1 +efsaneler.

Sezen, T. (2006). Osmanlı yer adları. Ankara: T.C. Başbakanlık Devlet Arşivleri Genel Müdürlügüü.

T.C. Üsküdar Belediyesi. (2017, 03 Şubat). K1z Kulesi. Erişim adresi: https://www.uskudar.bel.tr/tr/main/pages/kiz-kulesi/35

Tatar, R. S. (2012). Bu toprağın efsaneleri. İstanbul: Su Yayınevi.

Törökanov, E. (1989). Respublikalık arheologiya-arhitekturalık Burana Muzey-Kompleksi. Bişkek: Tarıh cana Madaniyat Estelikterin Korgoonun Kirgiz Respublikalık Koomu.

Türkhan, M. S. (2008). XVIII. yüzyılda Kız Kulesi. V. Üsküdar Sempozyumu içinde (s. 653-664). İstanbul: Üsküdar Belediye Başkanlığı Üsküdar Araştırmaları Merkezi.

Ürekli, M. (2018). Kırgızistan'daki eski yerleşim yerleri ve tarihî kalıntıların değerlendirilmesi: 
Balasagun, Ak-Beşim, Sarıg (Krasnaya-Reçka). Osmanlı Mirası Araştırmaları (OMAD), (5) 11, 203215. doi: 10.17822/omad.2018.94.

Yakupoğlu, C. (2010). Türkistan'ın büyük Türk boylarından Çiğiller ve Anadolu'da iskân izleri. Tarih Araştırmaları, (29) 47, 103-136. Erişim https://dergipark.org.tr/tr/pub/tariharastirmalari/issue/47784/603649.

Yıldız, B. (2014). Balasagın-Burana Açık Hava Müzesi ve Arap harfleriyle yazılmış mezar taşları. Tarih Okulu, (XVIII) 7, 193-194. doi: 10.14225/Joh499.

Yörükân, T. (2006). Yunan mitolojisinde aşk. İstanbul: Türkiye İş Bankası Kültür Yayınları.

\section{EKLER}

Fotoğraf 1: Burana Kulesi ve balballar. (2017), Yazarın kendi çektiği fotoğraf. Fotoğraf 2: İstanbul Kız Kulesi. (2016), Yazarın kendi çektiği fotoğraf. 